\title{
Conquest and Care for the Preservation of Nature and Environment in the Novel Amba by Laksmi Pamuntjak: Study Ecocriticism
}

\author{
Wiyatmi \\ Yogyakarta State University \\ Email:wiyatmi@uny.ac.id
}

\begin{abstract}
This study aims to analyse (1) how the characters in the novel Amba by Laksmi Pamuntjak conquest and care for the preservation of nature and environment, and (2) the depiction of nature and the environment in relation to the overall story of Amba using ecocriticism perspective. The results are as follows. First, the nature and the environment of Buru are described as an arena to be conquered by the main character (Bhishma), who was a political prisoner in the New Order era. In addition, the preservation of nature and environment of Buru Island also should be protected from exploitation, especially by outsiders who came to the island of Buru. Second, the depiction of nature and the environment in $A m b a$ is related to the creation of the setting of story (place and time), i.e. Buru Island as political prisoners' detention place in the New Order era, between 1969-2006. From the perspective of ecocriticism these findings demonstrate how an island that was secluded so used to dispose of political prisoners have experienced the dynamics of an arena which was originally a natural and fierce, eventually turned into an island that invites entrants to explore and exploit natural wealth, so must be preserved.
\end{abstract}

Keywords: Buru Island, ecocriticism, environment, nature, political prisoners

\section{INTRODUCTION}

Natural disasters are happening everywhere. One reason is due to human behaviour that often does not consider the negative impacts on the balance of nature and environment. To support the continuation of human life we, human beings, cannot be separated from nature and the surrounding environment. It is the nature that provides source of food and energy for humans, also providing materials to build houses, castles, and other various means of human life. Therefore, humans must care for and preserve nature and the surrounding environment.

The attention to nature and environment has penetrated many areas of science, including humanities. Ecocritics study and ecofeminism in Indonesia also began grow, as evidenced by the publication of books such as Interpretation ecofeminism in Religion, Education, Economics, and Culture (Candraningrum, et al., 2013). Other than that, the emergence of the green literary movement, in Indonesia, among others, was initiated by the community Raya Kultura pioneered by novelist Naning Pranoto, showed a serious concern from a number of writers and literature lovers of nature and environment (www. rayakultura.net). In a green paper written by Naning Pranoto, he states that literature has the potential to offer inspiration and a call to save the earth www.rayakultura.net).

Amba novel (2012) by Laksmi Pamuntjak is 
one novel that tries to describe the relationship between humans with the nature and environment intensely. Nature and environment in the novel are described as a very important thing to support life of the characters in the novel. Especially since these figures are living in exile, as political prisoners at Buru Island in the New Order era. They had to subdue and cultivate nature and the harsh environment and wildlife to be able to survive in exile for many years.

Departing from this background, this research tries to examine the relationship between nature and environment in the novel of Amba by Laksmi Pamuntjak by using ecocriticism. From this study, it is expected that how the characters in the novel, which is a representation of political prisoners during the New Order who must survive for many years into exile on the island of Buru can be revealed. In addition, it can also be understood how nature and environment has inspired the writing of literature, especially novels in Indonesia.

The issues examined in the study are (1) how the characters in the novel Amba works Laksmi Pamuntjak conquest and care for the preservation of nature and environment, and (2) the depiction of nature and the environment in relation to the overall story of Amba using ecocriticism perspective. The results of this study are expected to be useful for the development of literature, especially literary criticism using ecocriticism study. In addition, the practical results of the study are expected to be useful for increasing appreciation of literature, particularly in understanding the relationship between literature and nature and environment.

This study uses ecocriticism perspective, which is study of literature linking the physical environment, population growth, the loss of wilderness and wild, with the rapid extinction of species, as well as increased contamination of air, water and soil of the earth (Love, 2003: 2). Ecocriticism gives an attention to the mutual relationship between literature and the environment, including the relationship with the social and physical reality, which is usually a concern in ecology (Love, 2003: 1). Ecocriticism will explain how nature, environment, with various issues become an integral part in the literature (Glotfelty \& Fromm, 1996: 70). In this case, the nature and the environment are not only understood as a backdrop and atmosphere, but also an aspect that helped build the aesthetics of a literary work.

In literature, such as a novel, natural and environmental problems are seen in the background (place and atmosphere) which are elements that are not separated from the characters, the language is used to convey the story, and the context of the story that supports the overall meaning of the novel. This is in accordance with the opinion of Sayuti (2000) that background, which refers to a particular place and nuance is to function as an atmosphere that supports the character of the novel.

Nature and environment are areas of study in the humanities, in particular by using ecocriticism perspective. In the paradigm of the humanities, ecocriticism is a kind of literary criticism that is relatively new because it became known in the 1990s. The publication of books Ecocriticism Reader (1996), edited by Cheryll Glotfelty and Harold Fromm and The Environmental Imagination (1996) by Lawrence Buell marked the emergence of ecocriticism in literary criticism (Aziz, 2010). Likewise, the publication of the work Ecocriticism, by Dreese Donelle N. (2002) shows the development of ecocriticism study in literary criticism.

As a relatively new work, first published in September 2012, the novel Amba has not been much studied by researchers. However, this novel has been discussed and commented on by a number of critics, among others Bambang Sugiharto and Goenawan Mohamad, Dewi Lestari, and Ariel Heryanto are shown inside the cover of the novel. Sugiharto (2012) states that it is indeed the novel tells a lot about the tragedy in " 65 with various psycho-social consequences. But it is not an exaggeration to say that in terms of maturity, the mastery of materials, erudition and the depth of human vision, and expertise by its shape, $A m b a$ is a novel of world class standard. In Indonesia alone, presumably this is one of the new peak in the achievement of our literature. Goenawan Mohamad (2012) considered that this novel would be one of a row of prominent works of Indonesian literature. Dewi Lestari (2012) stated that by using stunning diction Laksmi Pamuntjak brings colossal simultaneously touching love story. Not only romance, many aspects and learning of the history of life are revealed in this book. Ariel Heryanto 
(2012), stated that the love story is told by graceful and passionate motion by the most intelligent writer of his generation, set in the history of the most taboo time in our own land. From the various comments and assessment of the novel, it seems that nature and environmental issues contained in the novel have not been discussed (mentioned). In fact, the depictions of nature and environment are quite dominant in the novel, as in the following passage:

On the island of Buru, the sea is like a mother: in and awaits/ Dew spreads like shattered glass, and daylight illuminates the silent fields. Then night would reveal what was lost by the glare ... (Pamuntjak, 2012: $15)$.

Di Pulau Buru, laut seperti seorang ibu: dalam dan menunggu./ Embun menyebar seperti kaca yang buyar, dan siang menerangi ladang yang diam. Kemudian malam akan mengungkap apa yang hilang oleh silau... (Pamuntjak, 2012:15).

From the search for the results of previous studies, it can be concluded that the novel Amba has not been studied specifically, including by using ecocriticism perspective. Therefore, a study on the novel by using ecocriticism perspective needs to be done.

\section{METHOD}

To understand how the characters in the novel Amba works Laksmi Pamuntjak conquest and care for the preservation of nature and environment, and (2) the depiction of nature and the environment in relation to the overall story of $A m b a$ this study uses qualitative research with the ecocriticism interpretive approach. Descriptive interpretive qualitative approach studies objects in their natural context and attempts to understand or interpret the meaning attached to humans (researchers) to him (Denzin \& Lincoln, 1994: 2). To achieve the research objectives, the research steps include determining the data sources, data collection and interpretation of data analysis concluded with the discussion and conclusion. Data was collected by the read and note technique. Data obtained by reading and recording information relating to the problems of research in the novel Amba and secondary data sources that is relevant to the research problem.

The data source is the novel Amba by Laksmi Pamuntjak, second edition published by Gramedia Pustaka Utama, in November 2012. The first printing of the novel was in September 2012. The novel consists of 494 pages. In addition, this research also used data sources relating to nature and environment depicted in the novel $A m b a$, which will be pursued from the literature relating to the ecology. Data was analysed by using qualitative discourse analysis approach of ecocriticism interpretive through categorizing, tabulating, and inference. Categorization is used to classify data based on predefined categories, namely the relationship between nature and environmental issues contained in the choice of words, sentences, discourse used in the text of the studied novel. Tabulation is used to encapsulate the entire data in tabular form. Inference is used to interpret and summarize the results of research according to research problems.

\section{Conquest and Care for the Preservation Nature and Environment in the Novel Amba}

Before explaining how the characters in the novel Amba struggling to conquest and care for the preservation of nature and environment Buru, it is necessary first described the outline of novel $A m b a$. $A m b a$ is dominated by stories about $A m b a$ who are looking for traces of her lover, Bhisma on Buru Island. Bhisma who works as a doctor, is regarded as a member of the Communist Party Indonesia (PKI) that the New Order was dissolved by the government and members of the PKI were taken prisoner after being involved in the September 30th Movement of 1965. As with other political prisoners, Bhisma was eventually sent to Buru, having previously held in Jakarta and the Nusa Kambangan Island.

Prior separated by political events known as the Movement of $30^{\text {th }}$ September 1965, Amba, who at that time was a student of English Literature, at the University of Gadjah Mada has intimate relationship with Bhisma and was pregnant. Bhisma was arrested by security forces along with $A m b a$ when they were attending a meeting at the Respublika University, Yogyakarta that was suspected relating to the Communist Party 
of Indonesia. Because not she could not find her lover, she finally decided to marry Adalhard Eilers, guest lecturer (native speaker) at Gadjah Mada University and lived in Jakarta and gave birth to a child named Srikandi.

After the political prisoners were repatriated to their respective regions in 2006, Bhishma was never to return. This has encouraged Amba to look for him on Buru Island. Amba wanted to know if Bhisma is still alive or dead. However, once Amba arrived on the island of Buru, she never found Bhisma, as Bhisma was already dead. He just found a lot of letters and stories about the live of Bhisma from his companions on the Buru Island. In those letters and stories that is, the relationship between nature and environment are depicted intensely and become the source of research data.

In addition to describing the close relationship between the figures with nature and the environment in a novel Amba described how the characters, which is the political prisoners had to fight nature and the environment are still natural Buru Island so that they can survive. Nature and the environment are described as an arena to be conquered and made friends, especially by the main character Bhisma. In addition, also described how the natural and living environment Buru Island should remain preserved after infiltrated by outsiders, even the owners of capital who would exploit nature.

The condition of Buru Island's nature which is still natural must be conquered by the political prisoners. By the New Order government, Buru Island was used as a penal for political prisoners who are considered involved in the Indonesian Communist Party and in the September 30th Movement of 1965. In the VIII Conference of National History in Jakarta, Alkatiri (2006: 6) suggested that the choosing of Buru Island as a prison was motivated by three things, namely (1) Buru is away from the capital city in which the political climate was very sensitive, (2) to alleviate the financial burden of the government for the success of Pelita (Five Years Development) program, (3) to continue to build infrastructure since 1945 that seek dams irrigation and agriculture. This is because the political prisoners on Buru Island will be sufficient for their own lives, without depending on the state financial budget. Therefore, in order to stay alive, then the political prisoners, likewise in the novel Amba, Bhisma had to change the forest into rice paddies and fields, as shown in the following excerpt.

That what he told me, "those who dump us here, used us to change this island for them. By changing rice fields with vegetation to consume dan constructing roads. In fact, this island was prepared to jail us. This valley is a prison. Natural oval-shaped landscape in which the three directions are surrounded by lush jungle and humps of mountains. The last cardinal point is bordered by sea. A cage. Tefaat (Pamuntjak, 2012: 59).

Ini yang dikatakannya kepada saya: "yang membuang kami memanfaatkan kami untuk mengubah pulau ini bagi mereka. Dengan membuat sawah, dengan menanam tetumbuhan untuk makan dan diperjualbelikan, dengan membuka jalan. Tetapi pulau ini sebenarnya telah disiapkan untuk mengurung kami. Lembah ini sebuah penjara. Alam cekung yang tiga arahnya dikitari tembok hutan belukar dan perbukitan yang sambung-menyambung. Arahnya yang keempat dikepung laut. Kurungan. Tefaat. (Pamuntjak, 2012: 59).

The quote is a dialogue between Bhishma with his friend, a native of Buru, Manalisa. From these quotations, it also appears that the condition of Buru Island is surrounded by wall of woods and hills; the fourth direction is a sea, a surrounded and isolated prison. After the detention period run out, Bhisma was unwilling to return to Jakarta. He chose to stay in Buru because he did not have anyone and just wanted to garden (Pamuntjak, 2012: 64). In Buru, Bhisma continued to live his life with gardening and served those who needed help, as a doctor.

The development of Buru Island from jungle until becoming a natural and lush environment with rice paddies, fields and plantations, according to Hersri Setiawan (2004: 127), one of the political prisoners, are things that are not planned by the government.

Buru Island developed into something they (government) did not expect. The place that they designed to be a hell hole 
for the communists turned out to be a haven for rice and spices, cajuput oil, wheat and sugar. Buru did not turn out to be a pesetran ganda mayit... (place for the dead). In fact, Buru became the breadwinner for Maluku Province (Setiawan, 2004: 528).

Pulau Buru ternyata berkembang tidak sesuai dengan rancangan mereka (baca: pemerintah). Yang mereka rancang menjadi lubang kubur komunis, tapi yang tumbuh padi dan palawija, meranti dan kayu putih, sagu dan gula. Buru tidak menjadi pesetran ganda mayit.... Sebaliknya, Buru menjadi tulang punggung "hidup mati" Provinsi Maluku.... (Setiawan, 2004: 528).

From the opinion of Hersri Setiawan, it appears that the political prisoners who were sent to Buru Island were largely a group of strong figures and unyielding to the circumstances and nature. They were trying to survive by opening the rice fields and forest.

Forests are also regarded as a friend for the figure of Second Women (Bird Face). This figure discovered peace in the middle of the forest. In fact, she was often in dialogue with the trees in the forest and criticized the deforestation, as shown in the following excerpt.

The Second Woman sought peace in the middle of jungle. (She decided to "gander at the moon"). It was told that recently, she was in need for that, not only "gander at the moon", but also to wander out from the jungle into the light, out into a small field in the middle of jungle. She just felt to be the urge to be there, just at the time where no one can see her dancing inside under the moonlight. She also wanted to greet the trees that became endangered. Because the wood cutters are often near (Pamuntjak, 2012: 17).

Perempuan Kedua tengah mencari kedamaian di tengah hutan. (Ia memutuskan "menatap bulan"). Diceritakan bahwa akhir-akhir ini ia merasa butuh melakukan itu, tak hanya untuk "menatap bulan", tapi juga untuk sesekali keluar dari pekat belantara, ke arah terang, ke sebuah lapangan kecil di tengah hutan itu. Ia merasa butuh tampil di sana, justru ketika ia tahu tak ada seorang pun yang bisa melihat dirinya di dalam petak-petak cerlang yang dibagikan bulan kepada gelap. Ia juga ingin leluasa menyapa pohon-pohon yang kian terancam. Sebab para penebang datang semakin kerap (Pamuntjak, 2012: 17).

It was told also that the Second Woman hugged the trees one by one as she whispered, feel the warmth of my body, feel the beats of my hearts, I am so in love with you. As she hugged those trees in a long manner, she cried tears. She hugged them just like her hugged the soil with the cry in the rain. This is not a strange thing for the Head Water clan. It is common for them to know that those tree were marked by the Second Woman were not only taken from their ground, but also carried away unlicensed truck to unknown places by those strangers. They also know that this upset the Second Woman and made her hopeless (Pamuntjak, 2012:17-18).

Diceritakan pula bahwa Perempuan Kedua mendekap pohon-pohon itu satu per satu sambil berbisik, rasakanlah kehangatan tubuhku, rasakanlah debar jantungku, aku begitu cinta padamu. Dan ia mendekap pohon-pohon itu dengan lama, dengan air mata. Ia mendekap mereka sebagaimana Perempuan Pertama mendekap gunduka tanah dengan isal yang menderaskan hujan. Lagi-lagi, ini tidak aneh bagai warga Kelapa Air. Mereka umumnya tahu bahwa pohon-pohon yang ditandai Perempuan Kedua tak hanya tercerabut dari tanah, tapi juga diangkut dalam truk-truk acap tak berpelat ke tempat-tempat tak bernama oleh orang-orang ta dikena. Mereka juga tahu, ini membuat Perempun Kedua marah, dan merasa tak berdaya (Pamuntjak, 2012: 17-18).

From both these quotations, it can be seen the seemingly intimate interaction between forests (nature) with the character (the Second Woman). She felt the need to find peace in the forest, enjoying the beauty of the moonlight. Additionally, in the woods, she also gave sympathy to the trees because the trees were cut by legal and illegal 
loggers. From these quotations, it is also expressed the criticism of logging practices which are not balanced by the planting of trees. Embracing trees in the perspective of ecofeminism symbolizes the chipko movement, a movement that refers to rally condocted in 1974 by twenty seven women in Northern India to protest the felling of indogenous trees that arms around the trees designated to be cut down (Tong, 2006: 394). Chipko in Hindi means to hug the three trunks to save food resources, fruits, and firewood (Rasmussen, 2016: 349). What the Secon Woman character has done in Amba can thus be seen as the manifestation of the chipko movement.

\section{The Depiction of Nature and Environment in the Novel of Amba}

In addition to describing the struggle of the characters in conquering nature and the preservation of nature Buru, depictions of nature and the environment in $A m b a$ is also related to the depiction of the background story. To describe the background of the place and time, nature and the environment used as a source of images, as shown in the following excerpt.

There was indeed a time when Buru was a place of sailors who settled there. The usually came from the islands of Buton and Bugis; strong, firm, the children of the sea.... Buru has become a magner. This island is full of stories, not just one colour... (Pamuntjak, 2012: 19).

Memang ada suatu masa ketika Pulau Buru kerap didatangi para pelaut, yang lalu menetap di sana. Mereka umumnya datang dari Pulau Buton dan Bugis: kokoh, tegas, anak-anak samudra.... Buru telah menjelma magnet. Pulau ini dengan kisah-kisahnya yang tak lazim, bukan satu warna... (Pamuntjak, 2012: 19).

On Buru, the sea is like the mother, waiting under the dew that drips like a stained glass, and the day that shone upon a silent field. As well as night will uncover what has been lost by the glare... (Pamuntjak, 2012:15).

Di Pulau Buru, laut seperti seorang ibu: dalam dan menunggu. Embun menyebar seperti kaca yang buyar, dan siang menerangi ladang yang diam. Kemudian malam akan mengungkap apa yang hilang oleh silau... (Pamuntjak, 2012: 15).

From these quotations, it appears that Buru was likened to a mother who is in the wait, it can be interpreted that the Buru is a region that is still filled with the richness of nature, whether in the ocean or in the woods, who was watching the children, future generations and newcomers to explore the natural and build it and create prosperity for its people. This corresponds with imagery that Buru Island is surrounded by the sea of deep and thick forests, which have natural resources.

Utilization of nature and the environment also appears in the description of the changing of time, morning, noon, and night on the island of Buru was described quietly in these descriptions: the dew that drips like a stained glass, and the day that shone upon a silent field. As well as night will uncover what has been lost by the glare [Embun menyebar seperti kaca yang buyar, dan siang menerangi ladang yang diam. Kemudian malam akan mengungkap apa yang hilang oleh silau]. It provides images that actually Buru still has unspoiled nature away from the noise and pollution.

In addition to describing Buru which is quiet and natural, it is also described the local wisdom of Buru Island, particularly in consuming deer as a game.

They talked about the best way to hang the deer, on its hind legs, so that all body fluids can flow smoothly crossing the nose and mouth without harming other organs, particularly the meat - as if he showed how to improve the design of human nature. Hearken, O fellow meat eaters: The deer that can be eaten just that that was killed with a single blow. Do not ever eat the brain, spine, spleen, especially the eyes. Never eat their eyes.

Samuel touched Amba's arm gently.

"You know," he said lightly, "parts of deer that we can eat have a much lower fat content than beef" (Pamuntjak, 2012: 40). 


\begin{abstract}
Mereka bicara tentang cara terbaik menggantung rusa, yaitu pada kaki belakangnya, agar semua cairan tubuhnya dapat mengalir dengan lancar meliwati pipa pernapasan hidung dan mulut tanpa mencemari organ-organ tubuh lainnya, terutama daging -seakanakan menunjukkan bagaimana manusia memperbaiki desain alam. Simaklah, wahai sesama pemakan daging: Rusa yang boleh dimakan hanyalah yang telah dibunuh dengan sekali tebas. Janganlah sekalikali makan otak, tulang punggung, limpa, apalagi mata. Jangan pernah menyantap mata mereka.
\end{abstract}

Dengan lembut Samuel menyentuh lengan Amba.

"Kau tahu kan," ujarnya ringan, "bagianbagian rusa yang boleh kita makan kadar lemaknya jauh lebih rendah ketimbang daging sapi." (Pamuntjak, 2012: 40).

From these quotations it appears how the local wisdom of Buru natives in consuming deer meat. In the excerpt, it is shown their respect for animals. Slaughtering deer should be in on slash, so that the animals do not feel pain. In addition there are parts that are not to be eaten: the brain, spine, spleen, and eyes. Besides, it is not good for human health because it contains fat, while the animal is still alive, is a part of the vital organs.

The close relationship of Buru's natives with the nature in also seen in the naming of the villages, Kepala Air (Water Head) (p.17) and Air Buaya (Crocodile Water) (p. 21).

You and I may be surprised to hear this description. But for the Waeapo's indigenous people, especially those living in the "Head of the Water", a term of the residents for the creeks upstream, there is absolutely nothing strange about ir. For them, embracing the dead is tantamount to embrace life. Anyway, Waeapo has seen many events-many events that take place on the ground, in the middle of a forest, in the rain. Event involving death, sex, or death and sex (Pamuntjak, 2012: 17).

Kau dan aku mungkin akan kaget mendengar deskripsi ini. Tapi bagi penduduk asli Waeapo, terutama yang bermukim di "Kepala Air", istilah penduduk buat hulu sungai, sama sekali tak ada yang aneh. Bagi mereka, merangkul yang mati sama saja dengan merangkul yang hidup. Lagi pula Waeapo telah melihat banyak peristiwaterlalu banyak peristiwa-yang berlangsung di atas tanah, di tengah hutan, di tengah hujan. Peristiwa yang melibatkan kematian, seks, atau kematian dan seks (Pamuntjak, 2012: 17).

... The man had said that he had seen the First Woman in the Air Buaya (Crocodile Water). Strictly speaking, she was leaving the house of the local soa (which in retrospect, adds Dr. Wasis, was not unreasonable). Everyone visiting Crocodiles Water is usually required to report to local soa head's home... (Pamuntjak, 2012: 21-22).

... Si laki-laki sempat menceletuk bahwa ia merasa pernah melihat Perempuan Pertama di Air Buaya. Tepatnya, perempuan itu sedang meninggalkan rumah kepala soa setempat (yang kalau dipikir-pikir, tambah Dr. Wasis, bukannya tidak masuk akal). Semua orang mengunjungi. Air Buaya biasanya diharuskan melapor ke rumah kepala soa setempat... (Pamuntjak, 2012: 21-22).

Waeapo and Kepala Air are the names of the sub districts in Buru Island, in addition to Namlea, Waplau, and Batabual (http://burukab.go.id/ web3). Water Head (upstream) is used to refer to indigenous people dwelling in Waeapo, Buru because they live near rivers, springs as a source of life.

From the perspective of ecocriticism these findings demonstrate how an island that was secluded so used to dispose of political prisoners have experienced the dynamics of an arena which was originally a natural and fierce, eventually turned into an island that invites entrants to explore and natural wealth, so must be preserved. Nature and the environment Buru has taught figures which are political prisoners during the New Order them to be able to live a hard and isolated on a remote island. 
Bhisma should be able to conquer the ferocity of nature Buru, in order to survive to live his life as a political prisoner. Therefore, there is no other way than nature as a friend, to cultivate the land which was barren and dead into rice paddies and fields. However, after Buru developed into rice fields and plantations, there was uncontrolled logging. That raises concerns Muka Burung (Birds Face), which is expressed by touching and dialogue with the trees in the forest are increasingly threatened on the verge of extinction, which is an expression of the Chipko (Tong, 2006: 394).

Buru as he background story in the novel, looks at the mentioning of the names of a place that is referential to a number of locations on the island of Buru and the surrounding areas, namely Namlea, Waeapo, Kapala Air, Air Buaya, Maluku and Ambon. The names of these places are aesthetically related to the background of the political prisoner people involved in the Communist Party during the New Order. In the political history of Indonesia, Buru has a special significance because it relates to the place of exile for the political prisoners. In the book of Pramoedya Ananta Toer (1995: 2), it is told that the first wave of prisoners set off to Buru Island was on August 17, 1969. In this case Pramoedya was included in the first dispatch to Buru, which amounted to 500 people. Bhisma according to the narrative of the character Manalisa in Amba came to Buru Island as the third wave of political prisoners (Pamuntjak, 2012: 59). Besides being known as a place for political prisoner, Buru Island is also known as Tefaat, like several times mentioned in the novel Amba (eg, page 59). Tefaat stands for Points for Utilization (Tempat Pemanfaatan) (Aklakiri, 2006: 3). According to Setiawan, the overall political prisoners sent to Pulu Buru is around 12,000 people, they consisted of prisoners of the Communist Party of class B, namely those who are considered to be indirectly involved in the September 30th Movement of 1965, and is regarded as a cadre (Alkatiri, 2006: 7 ). In this case the character Bhisma, was a prisoner classified as class B because in the novel Amba, it seemed that he was not directly related to the events of $30^{\text {th }}$ September 1965 Movement in Jakarta. In fact, he was arrested in Yogyakarta on October 19, 1965 after attending a discussion at the Respublika University (Pamuntjak, 2012: 289).
Depiction of nature and environment in novel $A m b a$ are attached to the character and the life of the characters, as well as setting of place and time that has aesthetic quality, strengthen this novel to be as a historical novel. In this case, Amba who tried recounting the lives of prisoners on Buru Island in the New Order era can be said to be a novel that tells about one of the historical events in Indonesia, which is the tragedy of 1965.

Although most of these figures are just the creation of the author (fictitious), but by sticking it with figures who are known to be real and historical event that ever existed in Indonesia, especially in the context of political prisoners on Buru Island in the New Order era, the previous fictitious aspects will become real and live or go through a stage of lifelikeness (Sayuti, 2000). This is in accordance with the opinion of Amarzan Loebis (2013), one of the former prisoners on Buru Island, which is now a senior editor of Tempo magazine, who says that the novel blends fictional and real material in a way that is very beautiful and intelligent, and $\mathrm{Amba}$ is also a part of the "struggle against forgetting" the wound of the nation's history that is never recovered (endorsement on the back cover of the novel $A m b a$ ). In addition to supporting its existence as a historical novel for readers, the depictions of nature and environment of Buru Island in Amba also invite readers to participate in living how the characters, most of who are political prisoners, had to struggle against the harshness of nature in the remote island. Readers are invited to sympathize with characters who survived and eventually made it home to his family, those who have conquered and friends with nature.

\section{CONCLUSION}

The results are showed the following findings. First, the nature and the environment Buru described as an arena to be conquered by the main character (Bhishma), who was a political prisoner in the New Order era. In addition, the preservation of nature and environment Buru Island also should be protected from exploitation, especially by outsiders who come to the island of Buru. Secondly, the depiction of nature and the environment in Amba related to the creation of the background story, which is setting the place and time, Buru Island detention of political prisoners 
in the era of the communists in the New Order era, between 1969-2006. From the perspective of ecocriticism these findings demonstrate how an island that was secluded so used to dispose of political prisoners have experienced the dynamics of an arena which was originally a natural and fierce, eventually turned into an island that invites entrants to explore and exploit natural wealth, so must be preserved. By critizing the exploration and exploitation of the natural resources of Buru Island, Amba attempts to call for struggle against politization and capitalism of the natural resources of Buru Island. Back to nature movement by Bisma and the chipko movement by Secon Woman character reflect such struggle. Thus, it can ce concluded that $A m b a$ not only brings the historical coup of 30 September 1965 back memory, but also brings forward ecological issues.

\section{REFERENCES}

Alkatiri, Zeffry. (2006). "Tujuh Buku tentang Pulau Buru." [Seven Books on Buru Island] A Paper presented at Konferensi Sejarah Nasional VIII in Jakarta, 13-16 November 2006.

Aziz, Sohaini Abdul. (2010). "Alam dalam Karya Shahnon Ahmad: dari pada Latar kepada Isu Alam Sekitar Pengarang Kreatif kepada Pencinta Alam Sekitar," [Nature in the works of Shahnon Ahmad: From the Background to the Issues] in Sastra dan Budaya Urban dalam kajian Lintas Media. A Proceding at Konferensi Internasional Kesusastraan XXI Himpunan Sarjana-Kesusastraan Indonesia (HISKI). Surabaya: Pusat Penerbitan dan percetakan Universitas Airlangga dan HISKI, pp. 65-77.

Candraningrum, Dewi. (2013). Ekofeminisme dalam tafsir Agama, Pendidikan, Ekonomi, dan Budaya. [Ecofeminism in the Interpretation of Religion, Education, Economics, and Culture]. Yogyakarta: Jalasutra.
Denzin, Norman K. \& Lincoln, Yvonna S. (1994). Handbook of Qualitaitive Research. Thousand Oaks, London, New Dehli: Sage Publications International Educational and Professional Publishers.

Dreese, Donelle N. (2002). Ecocriticism : Creating Self and Place in Enviromental and American Indian Literature. New York: Peter Lang Publishing.

Glotfelty, Cheryll \& Harold Fromm. (1996). The Ecocriticism Reader: Landmark in Literary Ecology. Athens and London: The University of Georgia Press.

http://burukab.go.id/web3. Retrieved from google.com, on 17 September 2014.

Love, Glen A. (2003). Practical Ecocriticism, Literature, Biology, and the Environment. USA: University of Virginia Press.

Pamuntjak, Laksmi. (2012). Amba. Jakarta: Gramedia.

Pranoto, Naning. "Sastra Hijau dan Eksistensi Bumi," [Green Literature and The Existence of the Earth] at www. rayakultura.net. Retrieved from google.com, on 10 Oktober 2013.

Rasmussen, Lary L. (2016). Komunitas Bumi, Etika Bumi. [Eart Community, Eart Ethics]. Jakarta: BPK Gunung Mulia.

Toer, Pramudya Ananta. (2004). Nyanyi Sunyi Seorang Bisu. [The Singing of A Mute] Jakarta: Lentera.

Tong, Rosemary Putnam. (2006). Feminist Thoght: A More Comprehenisve Introduction. Translate in Indonesia by Aquarini Priyatna Prabasmara. Yogyakarta: Jalasutra.

Suminto A. (2000). Berkenalan dengan Prosa Fiksi [Knowing Fictional Prose]. Yogyakarta: Gama Media.

Setiawan, Hersri. (2004). Memoar Pulau Buru. [Memoir of Buru Island] Magelang: Indonesia Tera. 